\title{
心臓移植患者15例の口腔所見と歯科治療
}

\author{
小野沢基太郎·金子裕之 之中里 慶子 \\ 山口達雄・割田雄司·阿部廣幸
}

\section{Oral findings and dental treatment in 15 patients undergoing heart transplantation}

\author{
Kitaro Onozawa $\cdot$ Hiroyuki Kaneko $\cdot$ Keiko Nakazato \\ Tatsuo YamaguchI $\cdot$ Yuuji Warita $\cdot$ Hiroyuki AbE
}

\begin{abstract}
Heart transplantation has substantially increased since cyclosporin became clinically available as an immunosuppressive drug in the 1980's, and the recent survival rate after heart transplantation has increased.

The major complication after heart transplantation is infection associated with the side effects of immunosuppressive therapy. Because we can prevent infection originating from oral lesions, evaluation of patients' oral health and removal of any potential source of infection is important both before and after heart transplantation.

We studied 15 patients after heart transplantation for whom dental examinations and treatment were requested by the Department of Internal Medicine of our hospital. Twelve decayed teeth were found in 3 patients, 52 teeth with marginal periodontitis in 4, 2 teeth with apical periodontitis in 2, 147 teeth with gingival enlargement in 9, mobility of a deciduous tooth in 1, 1 tooth with hypodontia in 1, and 1 fused tooth in 1 . All patients received an explanation on tooth brushing. Eight teeth were extracted in one patient during the period before and after heart transplantation. Dental calculi were removed from 22 teeth in 2 patients.

We report the details of these oral lesions and discuss the appropriate period for dental procedures and optimal antibiotic treatment.
\end{abstract}

Key words: heart transplantation (心臟移植), dental treatment (歯科治療), antibiotic（抗菌薬）

\section{緒言}

心臓移植は1980年代初めにシクロスポリンが臨床応用さ れて以来拒絶反応の抑制が容易になり末期的心不全に対す る治療として発展, 普及してきている1，2). わが国でも 1997 年10月16日より脳死臓器移植法が施行されて以来11例が行 われた.今後心臓移植予定の患者や心臓移植後の患者の増 加に伴いこれらの患者に対し口腔内の精査および管理を依 頼される機会も増加することが予想される.

心臓移植患者は移植後免疫抑制剂連用による易感染性の

東京女子医科大学附属第二病院歯科口腔外科

（主任：阿部廣幸教授）

Department of Oral and Maxillofacial Surgery, Tokyo

Women's Medical University Daini Hospital (Chief:

Prof. Hiroyuki Abe)

受付日 : 2002年 1 月 24 日

採択日：2002年 6 月 25 日
ため, 術前の感染源の精査が重要であるが外科的処置への 対応, 種々の免疫抑制剂自体の副作用, 術前, 術後の時期に よっては治療範囲の設定など多くの歯科的問題点が考えら れる。

今回われわれは口腔内精査依頼を受けた心臓移植前後患 者15例について臨床的に検討したので報告する．

\section{対象および方法}

対象は平成11年 1 月から平成13年10月までの 2 年 9 か月 間に 大学科より口腔内精査依 頼を受けた心蔵移植前後患者15例で, その内訳は心臓移植 術前に当科を受診しその後心臓移植術施行となった 2 例, 心臓移植術施行前後に当科を受診した 1 例と心臓移植術施 行後当科を受診した 12 例である.

今回性別, 年齢, 原疾患, 初診時の歯科的疾患およびそれ 
表 1 対象症例

\begin{tabular}{|c|c|c|c|c|}
\hline 症例 & 年齢 & 性別 & 原疾患 & 初診時の心臓移植状況 \\
\hline 1 & 16 & 女 & DCM & 術 後 9 年 \\
\hline 2 & 39 & 男 & DCM & 術 後 7 年 \\
\hline 3 & 16 & 女 & DCM & 術 後 6 年 \\
\hline 4 & 44 & 男 & DCM & 術 後 5 年 \\
\hline 5 & 13 & 男 & $\mathrm{DCM}$ & 術前 \\
\hline 6 & 46 & 男 & DCM & 術 後 3 年 \\
\hline 7 & 8 & 男 & DCM & 術 後 7 年 \\
\hline 8 & 13 & 女 & $\mathrm{RCM}$ & 術 後 4 年 \\
\hline 9 & 41 & 男 & $\mathrm{HCM}$ & 術 後 5 年 \\
\hline 10 & 5 & 男 & DCM & 前 \\
\hline 11 & 17 & 女 & DCM & 術 \\
\hline 12 & 4 & 男 & $\mathrm{DCM}$ & 術 後 1 年 \\
\hline 13 & 3 & 男 & $\mathrm{DCM}$ & 術後 6 か月 \\
\hline 14 & 29 & 男 & DCM & 術 後 6 年 \\
\hline 15 & 31 & 女 & M I & 術 後 1 年 \\
\hline
\end{tabular}

DCM: 拡張型心筋症 RCM: 拘束型心筋症

$\mathrm{HCM}$ : 肥大型心筋症 $\mathrm{MI}$ : 心筋梗塞

に対する処置などに関して調査検討した.

\section{結果}

性別は男性10例, 女性 5 例であった。患者の年齢構成は 最年少 3 歳 4 か月から最年長 46 歳10か月まで平均 21.7 歳で あり, 10 歳未満 4 例, 10 歳台 5 例, 20 歳台 1 例, 30 歳台 2 例, 40 歳台 3 例で10歳台が最も多かった. また原疾患別では拡 張型心筋症が12例と最も多く, 肥大型心筋症と拘束型心筋 症, 心筋梗塞がそれぞれ 1 例であった（表 1 ）. 初診時すで に心臓移植が行われていた 12 例の術後経過年数は平均 4.5 年であった。臟移植は全例ともアメリカにて施行されて いた。

当科初診時 15 例中 12 例に何らかの歯科的疾患を認めた. う蝕はう蝕 1 度を 1 例 3 歯に, う蝕 2 度を 2 例 3 歯に, う蝕 3 度を 1 例 6 歯に認めた. 辺縁性歯周炎は軽度 4 例 44 歯, 中 等度 3 例 8 歯に認め，また根尖性歯周炎は 2 例 2 歯に認め た. 2 例とも自覚症状は無く, 病巣は X 線写真上境界明瞭 で， 2 例とも直径 $3 \mathrm{~mm}$ 以下であった. 歯肉肥厚は 9 例 147 歯に認め, Harris-Ewalt Index $\left.{ }^{3}\right)$ では歯間乳頭の腫脹を示 す 1 度が 6 例, 歯間乳頭の腫脹および歯冠の 3 分の 1 を覆 う肥厚を示す 2 度が 3 例であった. 歯冠の 3 分の 2 を覆う 肥厚を示す 3 度および歯冠の 4 分の 3 以上を覆う肥厚を示 す 4 度は 1 例も認めなかった. 9 例中 8 例は初診時にシク ロスポリンと $\mathrm{Ca}$ 拮抗薬の両者を内服していた. その他, 永 久歯との交代のための乳歯の動摇を 1 例 1 歯に, また先天 異常としては歯数の不足を 1 例 2 歯に, 癒合歯を 1 例 1 歯 に認めた（図 1 ). 初診からの治療日数は最低 1 日, 最高 14 日で平均2.1日であった。

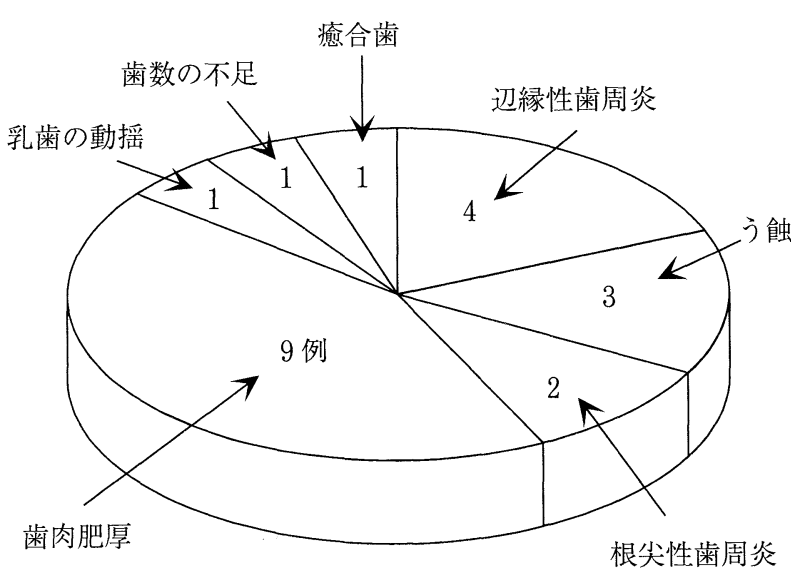

図 1 初診時の歯科的疾患

*複数の疾患を有した症例が存在するため, 症例数の合 計は, 対象とした15例と一致しない.

これらの歯科的疾患に対する処置は, 全例に対しブラッ シング, フロッシングを含めた口腔衛生指導を行い, 歯石 除去 2 例 22 歯, フッ化ジアミン銀の塗布 1 例 3 歯, 充填 · 歯冠修復が 2 例 3 歯であった. そして抜歯を 1 例に対し心 臓移植術前に 7 歯, 術後の再診時に 1 歯行った.

症例 2 および症例 6 は縁上, 縁下に歯石を認めたため歯 石除去施行 1 時間前に AMPC $2000 \mathrm{mg}$ 経口投与させた後 に歯石除去を行った。その後 2 日間 AMPC $750 \mathrm{mg}$ ／日を 経口投与した. また抜歯を施行した症例10は拡張型心筋症 の 5 歳の男児で, 当科初診時, 1 か月後に心臟移植のため 渡米が予定されており治療計画への影響を考慮し，う蝕 3 度であった EDBA｜ABは歯内療法を行わず，2回に 分けて抜歯した. また交換期にあった左側下顎 B も抜歯し た.患児は抜歯前日より肺炎の診断の下, CAZ 1500mg／ 日の点滴静脈投与を受けていたため当科では抗菌薬は処方 しなかった. 抗菌薬は 1 週間投与された。この間にう蝕 2 度であった左側下顎 D の歯冠修復処置を浸潤麻酔下に 行った.さらに約 1 年後に移植心評価目的での当院内科入 院時の口腔内精査依頼による再診時, 左側下顎 $\mathrm{E}$ 根尖相当 部に根尖性歯周炎による膿瘍を認め, 退院が間近であった ため歯内療法は行わず，抗菌薬の予防投与として抜歯 1 時 間前に $\mathrm{AMPC} 1250 \mathrm{mg}$ を内服させた後抜歯し，さらに術後 4 日間 AMPC $1000 \mathrm{mg} /$ 日を経口投与させた。 浸潤麻酔と しては 8 万分の 1 エピネフリン含有 $2 \%$ 塩酸リドカインを 1 歯につき約 $0.2 \mathrm{ml}$ から $0.9 \mathrm{ml}$ 用いた. 術中, 術後に動悸や 呼吸苦などの臨床症状の変化は認めなかった。辺縁性およ び根尖性歯周炎, 歯数の異常の160歯については処置をせ ず経過観察とした（表 2 )。いずれの処置のあとにも感染症 
表 2 対象15例の歯科的疾患とその処置

\begin{tabular}{|c|c|c|c|}
\hline 症 例 & 疾 & 患 & 処 \\
\hline 1 & $\mathrm{GH} I$ 度 7 歯, $\mathrm{C}_{2} 1$ 歯 & & 充填·歯冠修復 1 歯 \\
\hline 2 & $\mathrm{GH}$ I 度 3 歯, $\mathrm{P}$ (軽度) 1 & 14歯 & 歯石除去14歯 \\
\hline 3 & GH I 度26歯 & & 経過観察 \\
\hline 4 & GHＩI 度12歯, P (軽度) & 2 歯, (中等度) 1 歯 & 経過観察 \\
\hline 5 & & - & \\
\hline 6 & GH I 度16歯, P (軽度) & 4 歯，(中等度） 4 歯 & 歯石除去 8 歯 \\
\hline 7 & GH II 度20歯 & & 経過観察 \\
\hline 8 & GH II 度26歯 & & 経過観察 \\
\hline 9 & GH I 度26歯, $\mathrm{P}$ (軽度) 2 & 24 歯, (中等度) 3 歯, Per 1 歯 & 経過観察 \\
\hline 10 & $\mathrm{C}_{2} 2$ 歯, $\mathrm{C}_{3} 6$ 歯, 乳歯の自 & 動摇 1 歯, (移植後) Per 1 歯 & 充填 - 歯冠修復 2 歯, 抜歯 8 歯 \\
\hline 11 & & - & - \\
\hline 12 & & 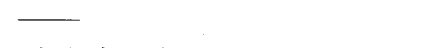 & - \\
\hline 13 & $\mathrm{C}_{1} 3$ 歯, 歯数の不足 2 歯, & , 癒合歯 1 歯 & フッ化ジアミン銀塗布 3 歯 \\
\hline 14 & Per 1 歯 & & 経過観察 \\
\hline 15 & GH I 度 9 歯 & & 経過観察 \\
\hline
\end{tabular}

$\mathrm{GH}$ : 歯肉肥厚 $\mathrm{C}$ : j蝕 $\mathrm{P}$ : 辺縁性歯周炎 Per : 根尖性歯周炎

状は認めなかった。

\section{考察}

心臓移植は 25 年前には 1 年生存率が $25 \%$ にすぎず，実験 的な試みであったが現在では末期的心臟病患者に対する主 な治療手段へと変化している4 ${ }^{4}$. 移植の適応となる疾患は 拡張型心筋症，および拡張相の肥大型心筋症と虚血性心疾 患, 心臟移植適応検討会で承認するその他の心疾患とされ， その適応条件も明確に定められている5 ${ }^{5)}$. 小柳ら ${ }^{6)}$ による とわが国における1984年から2000年10月16日までの渡航心 臓移植患者の総数は 55 名で平均年齢21.85 16.59 歳で男女 比36:19であったのに対し自験例でもほぼ同様の結果で あった. また欧米における心臓移植の適応となった原疾患 は約半数が虚血性心疾患であるのに対し7)，わが国では拡 張型心筋症が 41 例, 拘束型心筋症 5 例, 拡張相肥大型心筋 症 3 例, 川崎病 2 例となっており ${ }^{6}$ ) 自験例も同様，拡張型 心筋症が大半を占めるといった特徵が認められた．自験例 は全例アメリカに渡航していたが, わが国からの渡航先は 55 例中アメリカ42例と大半を占めている ${ }^{6)}$.

心臓移植患者の問題点は拒絶反応のコントロールとそれ に不可欠な免疫抑制剤の使用による日和見感染や免疫抑制 剂固有の副作用が挙げられる. 拒絶反応のコントロールで は術後急性期には一般的にシクロスポリン, アザチオプリ ン, ステロイドの三者併用療法を, 症例によっては OKT-3 モノクローナル抗体や抗胸腺細胞グロブリンが用いられる ことが多く ${ }^{8)}$, 術後 6 か月間はこれら免疫抑制剤の血中濃 度の微妙なコントロールや全身管理に重要な時期である。
心臓移植患者の死因においては移植後 2 週間以内では手術 手技や心原性の問題が死因のトップであるが 6 か月以内の 死亡では感染症が死因のトップとなっている ${ }^{9)}$.このこと より心臓移植予定の患者に対して術前に口腔内精査を行い 感染源と成りうる進行した重度の辺縁性歯周炎や症状があ る明らかな根尖病巣，う蝕などはおのおのの心疾患に対処 しながら積極的に治療すべきである。また Somacarrera ${ }^{3)}$ は口腔衛生指導を行わなかったシクロスポリンを内服する 心蔵または肝臓移植を行った46例中 37 例に歯肉肥厚を認め たと報告しており，口腔内の清掃状態を良好に保ち歯周病 の悪化や新たなう蝕の発生を防ぐ必要性を心臓移植患者に 理解させ, 清掃を継続させることも必要である.

また心臓移植の待機患者は, 全例重度の心不全であり移 植術の時期を失することは望ましくないため，歯科治療自 体の時間的余裕のない症例もあり主治医とのコミュニケー ションを十分にとり歯科治療を移植医療の一環として治療 計画を立案することが重要である。

心臓移植後 5 年までに冠動脈疾患が $50 \%$ の患者に発症す る1) とされ, さらに心臟移植患者は求心性の除神経により 心臓の虚血に対して狭心痛を自覚できないとされており歯 科治療に際しては動悸や悪心, 脱力, 眩暈, 呼吸困難に注意 しなければならない10)。

移植後の免疫抑制下において既存の慢性炎症の急性化を 予想することは難しく, 非活動性の辺縁性歯周炎や根尖病 巣に対する診断基準や対応は確立していない.

自験例においては中等度以下の辺縁性歯周炎については 1. 疼痛などの自覚症状がないもの. 2 . 腫脹や排膿を繰り 返した既往がなく現在もないもの．3．口腔衛生指導の後 
口腔清掃状態を良好に改善できるもの. また根尖性歯周炎 については 1 . 疼痛などの自覚症状がないもの. 2 . 根尖部 に腫脹や排膿の既往がなく現在もないもの．3．根尖病巣 が小さい（直径約 $3 \mathrm{~mm}$ 以下）もので X 線写真上病変の境 界が明瞭なもの.といった基準を置き，さらに個々の症例 に対する歯科治療に費やせる時間, 全身状態を加味したう え経過観察とした.ただし心臓移植患者を経過観察する際 は免疫抑制剂を使用しているため, 炎症の初期症状がマス クされていることがあり注意すべきである.

心臓移植患者に対する観血的処置への抗菌薬の予防投与 方法に一定の見解はないが, $\mathrm{AHA}^{11)}$ は, 拒絶反応がある時 期には, 後天的な弁の機能不全の危険性があることや免疫 抑制剂を連続して使用していることより，歯科治療による 心内膜炎の危険性は中等度のものとして分類している.さ らにBoraz ら ${ }^{12)}$ の報告によるとアメリカにおいて心臓移 植患者を診察した62施設中 54 施設が歯科処置に際し抗菌薬 の予防投与を必要と考え, 51 施設は処方の目的を免疫無防 備状態の感染予防としている.また40施設はAHA の推奨 する処方を行っており, 当科も予防を勧告されている処置 に含まれる抜歯, 歯石除去に対しては AHA の推奨する処 方に従い投与した. 観血的処置の時期としては, Little ら ${ }^{10)}$ によると移植された心臓は一度治癒すると感染性の心内膜 炎に対する感受性は低下するとされ, さらに Somacarrera $ら^{3)}$ は歯周外科は歯肉肥厚が安定する移植 1 年後より行 うことを推奨していることより移植直後は控えることが望 ましいと思われる。

われわれ歯科医師は今後増加するであろう心臓移植患者 に対し口腔管理による感染予防を通じてその予後に関与し ていく必要があると思われるが, 国内の心臓移植施設や移 植医療に関わる施設は少なく, 当院では遠方からの通院と なるため, 約 1 年に 1 度の移植心の拒絶反応を評価するた めの検査入院時にのみ当科を受診する例も多く, 現状は患 者個人の口腔状態に合わせたリコールを行うことが困難で ある.心臓移植患者に対する歯科的治療指針の早急な確立 と普及が必要と思われた。

\section{結語}

今回われわれは平成 11 年 1 月から平成 13 年 10 月までの 2 年 9 か月間に当院内科より口腔内精査依頼を受けた心蔵移 植患者15例について調査した。

1 ) 初診時15例中12例に歯科的疾患を認めた。 その内訳 は $\mathrm{C}_{1} 1$ 例 3 歯, $\mathrm{C}_{2} 2$ 例 3 歯, $\mathrm{C}_{3} 1$ 例 6 歯, 根尖性歯周炎 2 例 2 歯, 辺縁性歯周炎は軽度 4 例 44 歯, 中度 3 例 8 歯, 歯肉
肥厚 9 例 147 歯, 乳歯の動摇 1 例 1 歯, 歯数の不足を 1 例 2 歯, 癒合歯 1 例 1 歯であった.

2 ) 初診時全例に対し口腔衛生指導を行い, 歯科的疾患 に対して歯石除去 2 例 22 歯, フッ化ジアミン銀の塗布 1 例 3 歯, 充填 - 歯冠修復 2 例 4 歯, 抜歯を移植前に 1 例 7 歯, 移植後に 1 歯施行した. 処置に際し, 容態の急変は認めな かった。

3 ) 観血的処置に対してはAHAの推奨する抗菌薬の予 防投与法に従ったが術後の感染症状は認めなかった。

4 ) 今後さらに増加すると思われる心臓移植患者に対し 術前, 術後の歯科的治療指針の確立と普及が必要と思われ た。

本論文の要旨は, 第46回日本口腔外科学会総会 (2001年10月 26日, 鹿児島サンロイヤルホテル）において発表した。

\section{引用文 献}

1）小柳 仁：心臓移植総論. 東女医大誌 71: 254-262 2001.

2）白倉良太 : 心移植. 臨床検査 41: 911-914 1997.

3) Somacarrera, M.L., Lucus, M., et al.: Oral care planning and patients. Spec Care in Dentistry 16: 242-246 1996.

4）篠山重蔵：心移植の適応。治療学 32: 1176-1179 1998.

5）北村敂一郎：心移植の適応と本邦における問題点. 医薬の門 40: 47-54 2000.

6) 小柳 仁, 野々山真樹, 他 : 渡航心臟移植の現状と わが国における意義. 医学のあゆみ 196: 1101-1104 2001.

7) Hosenpud, J.D., Bennett, L.E., et al.: The rergistry of the international society for heart and lung transplantation. J Heart Lung Transplant 17: 656-668 1998.

8）布田伸一：小児症例における海外渡航心移植。 Heart View 3: 428-435 1999.

9）薗潤, 赤坂隆史 : 成人症例における海外渡航心 移植. Heart View 3: 420-425 1999.

10) Little, J.W. and Rhodus, N.L.: Dental management of the heart transplant patient. Gen Dent 40: 126-131 1992 .

11) Dajani, A.S., Taubert, K.A., et al: Prevevtion of bacterial endocarditis: recommendations by The American Heart Association. J Am Dent Assoc 128: 1142-1151 1997.

12) Boraz, R.A. and Myers, R.: A national survey of dental protocols for the patient with a cardiac transplant. Spec Care in Dentistry 10: 26-29 1990. 